\title{
PATHOLOGY OF MASS HOUSING PROJECTS IN IRAN (MEHR HOUSING PLAN)
}

\author{
G. Abbaszadeh \\ $\mathrm{PhD}$ in Urban Planning, Ferdowsi University of Mashhad, Iran
}

Published online: 15 May 2016

\begin{abstract}
Mass housing in construction industry is known as projects that mass production methods are used to construct residential units in it. Mass housing is a model of construction that has high economic, technical and managerial feasibility and should optimize three areas of quality, time and cost. But it should be noted that in one hand this pattern have its weakness and in other hand how to implement and enforce it, is of cases that would have different results based on efficiency and effectiveness. Since the construction of mass housing in Mehr housing projects has been one of Iran's government proceedings in recent years and has not been done comprehensive analysis about its results and effects, the present article try to analysis consequences of this pattern with pathological approach and descriptive - analytical method and outlines its advantages and disadvantages through review of some experiences in other countries. Consequences of this experience analyzed in five dimensions: procedure, economic, social, urban planning and environmental. Iran's experience shows mass housing is on the agenda with the goal of providing housing for low-income people and only in order to solve the problems of housing and the other aspect is neglected so finally will be lead to the destruction of the natural environment, social environment and city's physical environment.
\end{abstract}

Keywords: housing, mass housing, Mehr Housing Plan

Author Correspondence, e-mail: abbaszadeh59@gmail.com

doi: http://dx.doi.org/10.4314/jfas.v8i3s.268

\section{INTRODUCTION}

House as one of the basic requirements is one of the first issues that Man has always been struggling with it and always tried to transform it and find appropriate and reasonable in this 
regard. On the other hand, construction of housing with a high volume of turnover and to create sustainable jobs, social security and economic stability has consistently been among the deciding priorities of government officials. The industrial revolution in Europe followed by increasing housing demand due to the reconstruction of war led to different methods in order to meet this major demand. Today, in developing countries given the size and severity of the housing crisis, wide range of low-income groups, especially the urban poor, and limits their possibilities is necessary method of providing affordable housing more than ever.

One of the methods that Europe after the industrial revolution went into it in response to the major demand and can also be a suitable solution for developing countries in current situation is Mass housing that is in fact, a model of construction that have high economic, technical and management feasibility.

Perhaps this record can search during the ancient Egypt era that at the time, for thousands of workers that were responsible for building of pyramids, was built aggregated housing complexes with minimum facilities. In the words of today's, Mass housing have rooted in housing programs of European industrial cities after the industrial revolution that was made for housing rural migrants that had come to cities for work and in very polluted and dirty and inhumane environment (Naghizadeh,2004). In summary, the causes of the mass housing can be summarized as:

- Continuous changes in science and technology that is result of the continued intellectual and unremitting efforts of people in history

- Population increase that raised need to produce more in less time and has replaced thinking urban mass housing as a sustainable industry with previous methods (Van Goola et al,2008). Mass housing projects as one of the most important parts of project-based in the construction industry plays an important role in countries. These projects have the most important share in GDP and include about $60 \%$ of all construction projects (Khanzadi et al,2010).

In the last decade, housing strategy in Iran has emphasized mainly on the supply of social housing and its mass production (Mokhber,2002,40); based on this strategy, it is considered social housing goals with the adoption of minimum appropriate and acceptable standards and is remembered sometimes as strategy of " PAK" (savings, mass and downsizing).

In 2006, the average ratio of home ownership in Iran cities has been 68 percent on average; this figure is $56 \%$ for the lowest income deciles and $85 \%$ for the highest income groups (Department of Housing and Urban Development,2006,42). And indices of house prices to income urban families that must be between 3-5 times of the total family income, is about twice in Iran (Department of Housing and Urban Development,2008,4). Thus, in recent years, 
policies of housing for low- income urban groups formed based on issues such as the transfer of cheap land in different cities, subsidies for housing loans, hire-purchase housing units, creating funds and co-operative housing and 99-year housing plan (Heydari Chaîne and Rezatabe Azgami,2010,71).

In the fourth (2005-2009) and fifth (2011-2015) development programs After the Islamic Revolution, introduced Mehr plan as government policy in the field of housing And an attempt has been made to with remove land prices from the cost of housing, housing for lowincome groups be considered. In continuation of this policy, Mehr housing set on the government agenda and these projects has been started in many cities that some are operational and some are still in the making and implementation stage. But since this type of housing pattern as with many other issues follow the Western model of mass housing after World War II, Further evaluation needs about its fit with the culture and the needs of the target groups. In addition, since the policy (Mass Housing in the form of Mehr housing plan) in Iran has wide dimensions and has a major effect in its various aspects, and as ever did not a comprehensive analysis of the consequences of this template, this paper attempts to by knowing the mass model and its advantages and disadvantages and by a review of some of the experiences of other countries, illustrates the consequences of this template with pathological approach.

\section{Objectives}

the main objective of this research is to identify the consequences of Mehr mass housing pattern in Iran that for this purpose, Secondary objectives can be better addressed as follows:

- Identify problems and issues of the implementation of Mehr housing plan

-Analyze the consequences of Mehr housing in social, economic, urban development and environmental dimensions.

\section{Questions}

According to the above mentioned issues and since the purpose of this Article is to identify the consequences of mass housing patterns of Mehr plan in Iran, following questions are raised:

-What are the advantages and disadvantages of Mass Housing?

-has implementation of Mehr Housing in Iran been successful?

-what are Consequences of Mehr housing Plan in social, economic, urban development and environmental dimensions?

\section{Methodology}


To explain the phenomenon of mass housing, basically, systematic approach and holistic approach, Is the most appropriate analysis method; Because mass housing is not only way to build, But it's related to the social, economic and cultural structures and it accepts the interplay and appears in the physical realm.

Methodology of this research is Descriptive- Analytical and its nature is Theoretical and applied. Initially through documentary and library, paid to Explain concepts and definitions, and advantages and disadvantages of mass housing then According to a review of some mass housing experiences, Will be analyzed Mehr housing plan as one of mass housing patterns in recent years in Iran. Type of analysis is qualitative and the attempt is to be considered holistic in all aspects.

\section{DEFINITIONS, CONCEPTS AND THEORIES}

\section{-Mass production}

The concept of mass production was introduced in 1910 by Henry Ford to produce Ford car models (Bachelor,1994). Mass production which was also called serial or chain production was based on Standardize of elements and systematize of process. From the 1920s onwards the architects also tried

To solve housing problems, employ this paradigm. Two famous examples in this regard were Torten housing development by Walter Gropius in Germany and Pessac by Le Corbusier that both were designed around 1926. In both instances, there was a desire to create a plan that with industrialization as a means to reduce costs, create supportive housing (Kupferberg,1974). Their strategy was design a few models of housing that is prefabricated and then be repeated in large scale. Diversify was also important for Le Corbusier but this diversity concentrated more in urban scale. These examples and others were introduced on a trial basis for mass production of housing between the world wars; however a limited number of dwellings achieve little success.

After World War II, mass production was used largely in reconstruction of war devastated cities. In Eastern Europe, centralized form of government and social egalitarianism facilitate production and development of this process. Modular system in Eastern Europe closed systems that a factory produced all needed building elements and there was not inner change between different system elements. In Western Europe when housing shortage prevailed due to war, this type of production process was not accepted due to growing concern community about freedom and individual choice and so went into seclusion (Benros and Duarte, 2009,310). 
In America, need to build large-scale housing war raised after the war. Although the cities were not destroyed but the return of US troops and the subsequent marriage wave in America, create growing need to housing.

Therefore certain characteristics of American society and their impact on market forces led to different paradigm development for produce chain housing. In Europe, adoption of closed systems prevent internal change but in America, the willingness of manufacturers to avoiding of dependence to other producers brought them towards open systems gradually (Clark Jr,1986). These systems needed significant coordination to integrate elements of various providers. Production costs fell because any company was focused on production of certain elements and enabled them to optimize this process. Anyway Communication problems were barriers to full integration and endangered cost controls.

In the 1960s, excessive uniformity and lack of character of mass production of housing led to trying to new design and production methods that allow to user participation and more urban diversity and caused gradually other ways replaced with traditional mass production. But in Third World countries, urbanization wave, rural to urban migration, high urban growth rate and then housing shortage are factors that made them to go to the mass approach and now also this approach is center of their attention.

With this history, mass housing projects in the manufacturing industry, is known as projects that apply methods of mass production in order to build housing units.

Mass housing is design and construction of standard housing units that usually run at a time and a place. The residential units can include row houses, tower blocks and multi-stored and semi-detached and detached housing (Khanzadi et al, 2010). Mass production is not industrial necessarily but if optimize 3 factors (quality, time and cost) will be industrial mass production. The concept of mass-housing projects include projects that are more than 400 or 500 units (Ansari, 2007, 30-31).

Mass production should include features such as compliance with standard examples, cheaper, better quality, faster production and use of appropriate technologies. So who is mass construction that by using advanced methods of industrial-technical, new and resistant materials, Less time, lower costs and greater efficiency of urban land, can act to more produce and supply to the market (Nasiri, 2009, 119).

It should be noted that mass production can't be considered only as a model of housing but it is final result of a complex process that affect its performance by several factors including characteristics of cultural, social and economic. 


\section{-Mass building advantage}

Mass housing had many benefits that can be listed as follows;

1. Reduce the cost per square meters through;

-providing materials on a large scale that will be cheaper.

-The possibility of using of advanced technology including prefabricated buildings technology.

-Reduced costs for heating and cooling facilities.

-Reduction of construction time

-Reduction of labor costs (contractor, management ...)

2. Providing field for Improve the quality of construction Through the use of skilled manpower and industrial machines.

3. Efficient use of building materials

4. Providing more safety for residential units considering the technical supervision on construction due to the external reflection of these projects.

5. Possibility of innovation and creativity in management, design, construction and use of building materials

6. Possibility of using different financial resources, including bank facilities and the use of liquidity in the community

7. Achieve standards

8. Promote workforce skills due to needs of large-scale projects to special level of building technical knowledge

9. Diversity in the urban landscape

10. Having efficient city texture (If the principles and urban development criteria such as optimum use of land, flexibility, environmental protection, social justice and ... be respected)

\section{- Mass building disadvantage}

Despite of many advantages of mass building, it also has disadvantages that can be placed in three major groups: environmental and physical, psychological and socio-cultural.

\section{ENVIRONMENTAL AND PHYSICAL CONSEQUENCES}

Most mass projects are being done in marginal areas of cities; In other words, in places that agricultural lands have high value. Therefore, the use of these lands not only causes loss farmland but creates physical and social heterogeneity in the context of rural areas and creates a bizarre combination of people, bricks and cement. Types of visual, audio, water, soil and air pollution are negative consequences of increased density within areas which mass 
building is common. One facet of mass building is visual pollution. In other words residents through storage of excess equipment, leaving cooler waters and drying clothes in balconies of buildings make ugly face for city. This is a result of insufficient domestic housing space. In addition to increase building density and consequently boost car provides more noise pollution.

When a designer wants to design large housing units it is common solution that provides a limited number of types of housing and then repeats them on the basis of market analysis. There are two reasons to do this: First, the designer due to his amount of information cannot be designed for each housing individually and second, traditional manufacturing techniques needs this repeating to reduce costs (Benros and Duarte, 2009, 310). So the uniformity of the buildings in terms of shape, design, public and private spaces and materials create boring spaces that followed by numerous psychological consequences for residents.

\section{Psychological consequences}

It is now clear that humans and its environment interact in micro and macro scales. Priority in mass housing that mainly built for low and middle income groups is economic criterion not tastes or individual choice. So economic values are preferred on tastes and desires of individuals (Erman, 2004, 450) which cause some psychological consequences for individuals.

Feeling homesick is one of the negative consequences of living in big cities and especially mass housing that in a short period gather large crowds at many locations and with different cultural distinctions in one place. Loneliness, alienation, deconstructed and psychological pressure that dense urban society imposes on citizens increased depression, suicide, alcoholism, addiction, aggression, social and moral deviations, types of crime, divorce rate and also lack of interest in participating in social issues. Background of mass housing projects is equating the people which contain a certain negative consequences. In these plans does not pay attention to mental \& social different personalities of individuals and families and the home and housing is viewed as a machine. Such thinking intensifies identity crisis and alienation. Furthermore, because these projects don't designed and manufactured according to the residents' desire and need, intensify alienation and loneliness of man with their living environment and not provide psychological security of the residents actually.

To make attractive of mass housing, it is essential to provide architectural flexibility that means any new residential complex must have a different design and avoided from architectural uniformity. This is as need to diversify production (Bessant, 1991; Barlow, 1998). 
For suitable housing, multiple definitions are mentioned including: suitable housing is where that is safe from overcrowding. Despite the diversity of qualitative dimensions and different human needs how can we benefit from identical housing and similar for groups and different people? How can we neglect of consequences and effects of architecture on culture and psyche of human. The fact is that in new projects, especially in dividing spaces not considered customs of life in Iranian families. Therefore, Iranian family can't use from space of these building blocks as it is predicted.

\section{Social and cultural consequences}

Socially Housing is one of the major factors contributing to the balance and existence of human society. Housing Maintain the integrity of the family and relations of its members. Having suitable housing, like other human needs is considered as basic human rights. Iranian cities in the past had hierarchy model. Every city According to the environmental and economic requirements had Proportional and balanced population. But in recent decades, rapid growth of urban population allows to major cities that downsizing housing is its consequence. Congestion of people in one place reduces Familiarity and anonymity humans and provide appropriate context for violation of ethical principles or in other words, causes neglecting from moral beliefs. Assessments show that disregard for ethics in big cities in general and specifically in apartment is much higher than in smaller towns and rural areas. For example study of 1200 schoolchildren from four education regions in Tehran Showed that after parental education level, density factor is one of the most prominent factors in Evaluation of children's education. The study also concludes that overcrowding at home don't affects only children but include all persons living in the house. Another disadvantage of Equal build housing is eliminating identity of cities. Such that in this equal build housing, cities become uniform and boring from; while identity of every city, Indicating the identity of intellectual, cultural, technical and ways of life of its residents. Other consequence is rapid transformation of the urban community culture and especially its dense parts to ward worldliness and non-spiritual condition. It is clear that in rural and small communities Attention was Respect for the traditions and religious beliefs But with human Overcrowding Spirituality and ethics threatened Seriously And the present man Has faced with Great and controversy challenge (Moghani Rahimi, 2008,53-55).

\section{-Mass housing and Tall building}

High rise buildings were considered serious as a new paradigm in urban development in a general sense and in construction of housing in particular in the early of twentieth century and emerged different schools such as Chicago and modernism. But what is now considered 
is in connection with the issue of sustainable urban development and efficient use of land and other productive resources. The major justifications in need of high rise buildings can be raised In terms of population density and building density issues. In this regard The pattern of high rise buildings are formed based on Economic, social, technical, and physical environment topics (Bemanian, 1998).

The relationship between mass and high-rise building has numerous foundations. On the one hand the trend of population growth, Growing need for housing And the demand for different patterns of residence and On the other hand severe restrictions on Response Source to provide needed housing (Especially land), complicated the issue of Housing planning. In terms of the above issues as well as different views about the residential patterns, High-rise building arises as a form of mass housing. This view Is more sensitive in large cities and Cities with the possibility of expansion Or in the cities that their physical expansion become Threatening agriculture and the environment. In such a situation, High-rise buildings appear with two clear goals: Increase building density and open space. Many high-rise buildings that constructed on a large scale can be considered as towns. In this case It is expected that be fulfilled Goals of a town. Here Criteria such as city landscape, environment, network, security and access to public facilities will be criteria of urban development. Aesthetics, urban landscape and urban spaces Criterias will be among the landscape of the city. Infrastructure including water, electricity, surface water and green space will be considered on the Environment dimension. In a communication network issue Hierarchy, access and Sidewalks are important. Also In the safety dimension Are raised Fire, materials, earthquakes and floods issues (Azizi, 1999, 44). In relation to the physical-spatial dimensions of mass and tall building arises spatial organization of the city where be considered All sociodemographic, cultural, historical and physical characteristics. In other words, three elements of the population, activity and space arise in such a context; Among them are: heterogeneity of life in urban neighborhoods, short Distance between residence and place of work, possibility of exchange between residents of the neighborhoods and Principle of adjacency. Therefore Optimal organization of elements And constitutive elements of spatial structure of the city Is necessary for High-rise construction in large scale. As a conclusion it can be said:

- Mass housing and high rise buildings are two different models completely.

-Mass housing could occur without high-rise building

- High-rise building does not have a strong relationship with mass housing. Relationships are In terms of infrastructure and the construction of housing units in a project.

\section{- Mass housing experiences}




\section{- Mass housing in Spain (Barcelona)}

Mass housing estates in Barcelona has built between the 50s and 70s through multistage And with different legal frameworks And by various agencies and executive programs Which aims to Solving existing problems at the time include homeless And create neighborhoods with substandard housing As a result of massive immigration flows And eradicate exiting slums. The emergence of this housing caused rapid growth of the city in the historical period. Mass housing estates have located on the outskirts of cities that have been significant changes in the structure and shape of the city and Beginning to create Metropolitan area. The biggest impact on city has been Construction of 745,682 housing units and population growth around 1.5 million people during the period from 1950 to 1975 .

Despite Projects have been time-symmetric In terms of practical operation and despite large size of their land In terms of length and width, these housing have not been scheduled for mass housing and not for complex shape. The result was urban Growth through simple integration in the residential sectors that Located in urban territory Regardless of the strategic criteria of the urban landscape and major deficiencies in the structure And conjunction with it.

Urban model of mass housing estates has been direct production with the aim of making large amounts of housing in the shortest possible time and with the least possible financial investment. Therefore, the planning, management and administrative processes had been facilitated to maximum possible. As a result of these issues, Emerged Smooth and risky blocks both in terms of typology and construction and formed neighborhood that included A series of separate buildings on the land Without living tissue integrity Or the relationship of the cosmogenic Before the creation of housing And public space remained as empty space That has been neglected (Ayala,2011).

\section{- Mass housing in India}

In 2007 (the end of the sixth five-year plan India), there is around 24.7 million-house shortage in India on an average (National Building Organization, NBO \& NHHP 2007). Most of the shortage (99\%) is for the lower income group (LIG). As Table 1 shows this number among low-income groups is $10.5 \%$ while in middle and upper income groups is only $0.2 \%$. 
Table 1. Shortage of housing in the cities of India

\begin{tabular}{|l|l|l|l|l|}
\hline & $\begin{array}{l}\text { Monthly per } \\
\text { capita } \\
\text { expenditure }\end{array}$ & $\begin{array}{l}\text { Estimates of the } \\
\text { number in } \\
\text { households (2007) }\end{array}$ & $\begin{array}{l}\text { Housing } \\
\text { shortage } \\
\text { millions (2007) }\end{array}$ & $\begin{array}{l}\text { Percentage } \\
\text { of shortage }\end{array}$ \\
\hline $\begin{array}{l}\text { Weak economic } \\
\text { groups (EWS) }\end{array}$ & $0-3300$ & 21.81 & 21.78 & $99.9 \%$ \\
\hline $\begin{array}{l}\text { Low income } \\
\text { groups (LIG) }\end{array}$ & $3301-7300$ & 27.57 & 2.89 & $10.5 \%$ \\
\hline $\begin{array}{l}\text { Middle income } \\
\text { groups (MIG) }\end{array}$ & $7301-14500$ & 16.92 & 0.04 & $0.2 \%$ \\
\hline $\begin{array}{l}\text { High income } \\
\text { groups (HIG) }\end{array}$ & $\begin{array}{l}14501 \\
\text { above }\end{array}$ & & & \\
\hline Sum of shortage
\end{tabular}

It is also envisaged that during the eleventh five-year plan (end of 2012) sum of housing needs reach to Approximately 26.53 million units for 75.01 million households considering the lack of available and if to be maintained the current rise in housing Will be required At least 30 million additional housing in 2020. Indian national programs and policies over the past decades has shown that government has played the role of direct provider of housing and more has focused on facilitating private developers and a joint venture to make more housing. Now also with the joint efforts of the central and state government Framework of a comprehensive approach is increasing to overcome the housing shortage.

Housing shortage in India has not resolved with housing shortage system. Based on study of 5-year performance of India Public key issues for not providing mass housing during different periods is derived as follows. The arguments based on qualitative assessment during design period have been counted From 20 to 10. Overall faster Housing system and Funding and support have known as the most important issues that need for the solution. 
Table 2. Analysis of important issues and barriers in the provision of public mass housing

\begin{tabular}{|c|c|c|c|c|c|c|}
\hline Issues / obstacles & $\begin{array}{c}\text { Third } \\
\text { and } \\
\text { Forth } \\
\text { program } \\
(1961- \\
\text { sixth } \\
\text { program } \\
(1971-81)\end{array}$ & $\begin{array}{c}\text { Fifth and } \\
\text { seventh }\end{array}$ & $\begin{array}{c}\text { Sixth and } \\
\text { program }\end{array}$ & $\begin{array}{c}\text { eighth and } \\
\text { ninth } \\
\text { program } \\
(1981-91)\end{array}$ & $\begin{array}{c}\text { Tenth and } \\
\text { Eleventh } \\
\text { program } \\
2001)\end{array}$ & sum \\
$(2001-2011)$ & & \\
\hline $\begin{array}{c}\text { Funded and supported } \\
\text { housing }\end{array}$ & 20 & 20 & 20 & 15 & 10 & 85 \\
\hline $\begin{array}{c}\text { Institutional and policy } \\
\text { framework }\end{array}$ & 15 & 15 & 10 & 10 & 10 & 60 \\
\hline Access land for housing & 10 & 20 & 15 & 15 & 10 & 70 \\
\hline $\begin{array}{c}\text { Improving access and } \\
\text { building materials }\end{array}$ & 15 & 10 & 15 & 20 & 20 & 80 \\
\hline $\begin{array}{c}\text { Technology systems } \\
\text { faster and housing }\end{array}$ & 20 & 15 & 15 & 20 & 20 & 90 \\
\hline $\begin{array}{c}\text { Skilled and unskilled } \\
\text { labor }\end{array}$ & 10 & 10 & 15 & 10 & 20 & 65 \\
\hline
\end{tabular}

Since current technology and housing providers (public and private market) Cannot resolve housing needs it is needed Faced with an advanced system that is Faster, more efficient, and environmentally sustainable. Finally, when housing demand for the higher income reached groups to half saturation Developers have to invest in housing for low income measure. Construction industry that was used to this mass housing has been pre-fabricated housing system that With this method, Energy efficiency is More than $60 \%$ of normal way (Uttam et al, 2011).

\section{- Mass housing in Turkey}

Turkey has been met with the notable housing problem especially in big cities in the 1950s. Different development rules lay to solve this problem and overcome the housing shortage and have been used various methods to meet the need for housing. The final step to achieving this goal was mass housing. Because of the housing shortage in Turkey is 100,000 to 200,000 housing units per year, Production and manufacturing techniques to mass housing is One of the major issues (Koman and Eren,2010,59). 
Mass production of housing in Turkey Became widespread Through housing cooperatives Because of granted incentives In the late 1970s (Aydemir,1990,137). Mass housing administration of Turkey was founded in 1984 and is responsible for planning of Urban areas In order to solve the need for housing and to Grant mass housing loans to low and middle income groups. In 1984, with mass housing law, Funding was formed for mass. In the same year to confront with the housing needs of low-income groups created a new legal entity with name Mass-Housing Authority (MHA). Its objectives as specified below:

- Providing housing for low and middle income groups with no home.

- Create options for the opening of new residential areas with infrastructure that will follow elimination of slum settlements.

- Providing financial support for housing

- Collect public funds for urban development and housing production

- Providing new sources and uses it for housing purposes.

MHA is owner nearly half of real estate. Monetary credit and Real Estate of real estate Bank Was transferred to MHA in 2002 and boosted its financial strength. MHA share in housing Increased Of $0.6 \%$ between 1984 and 2002 to $24.7 \%$ in 2004. MHA had built 50183 residential units in Istanbul that it's Housing production models are as follows:

- Housing at the time of accident

- Urban transformation projects (projects slums Change)

- Production housing on MHA lands for low and middle income groups.

In fact, MHA Realize Housing regulation through housing policies and is as provider of Credit, land and empowerment at the local level. Recently, in order to lighten the administrative burden MHA Has begun sharing of benefits with the private sector (Yuksel and Gokmen,2009).

MHA is meeting the housing needs of mainly the middle-income groups. The urban poor, who constitute the bottom end of the low-income groups, and who usually have no ready assets for immediate purchase, are to be provided with housing in the long run. They become a kind of tenant in the meanwhile and pay rents not to a landlord but to the Authority by giving no down payment and paying a monthly amount for up to 20 years. At the end they own the unit. Otherwise they would have to rent a less quality home and pay some money monthly for many years before owning, if at all possible. Normally, all the rent they have paid so far would have evaporated. Thus the opportunities for the lowest income exist in MHA projects because the installments are low (no down payment, and repayment of credit is US\$ 100 per month), although the houses are quite small (55-65m2). The low-income 
groups, another target profile, are expected to make a small down payment (US\$2670 and repayment US\$ 170 per month,) but they have relatively larger units at the end $(65-87 \mathrm{~m} 2)$. Similar to the lowest group, they have long term repayments (about 15 years) (Bayraktar, 2008).

The source generation for large scale mass-housing projects had been through, for example, consumption taxes, oil products taxes, exit fees for departing tourists and credit returns in the past. Recently MHA has initiated alternative ways, such as using a revenue sharing model in which the private sector, i.e., developers and contractors, is involved. MHA is a non-profit government administration. The public bodies, mainly MHA, are usually supported by such mechanisms as banks, cooperatives and contractors. The housing policies are closely related to the work of such institution(s) because there should be harmony between the two, rather than conflict.

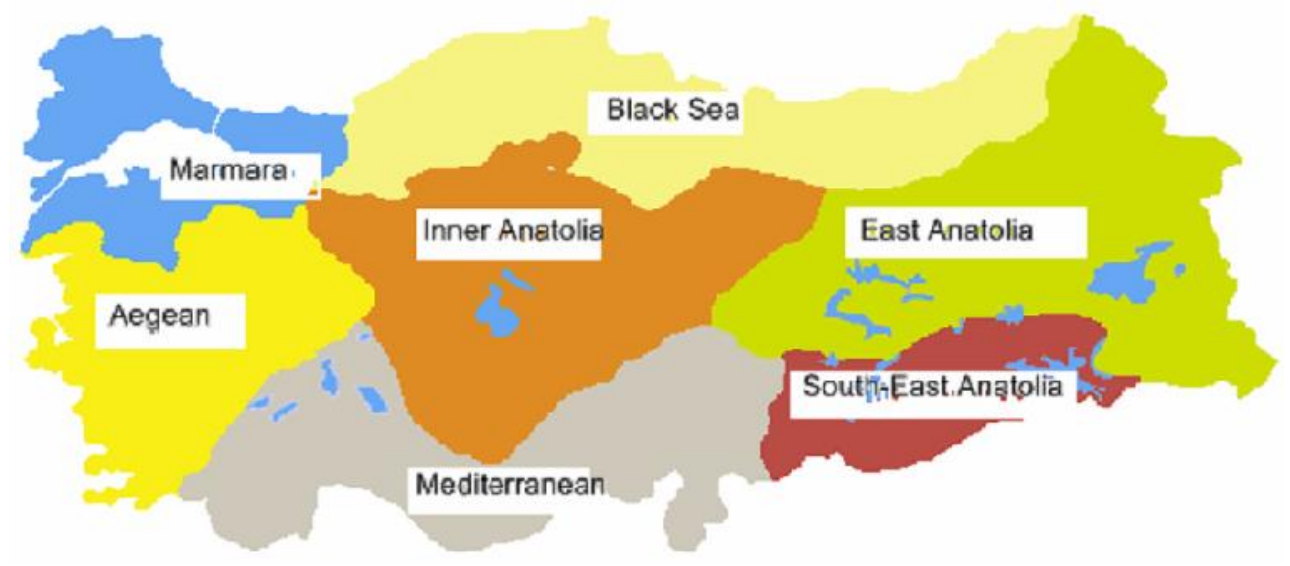

Fig. 1. Administrative Regions of Turkey

The scale of the projects, although they vary, is usually very large. In Turkey there are 7 administrative regions as figure 1 shows. Each of these regions is characterized by different climates and sub-cultures. It can be said that MHA has built more high rise housing projects which have more housing units, in the western part of Turkey than in the eastern part. These projects make a significant impact on the expansion of the cities in terms of population and construction density (Yuksel and Gokmen,2009). 
Table 3. Completed and on-going projects of MHA in Turkey

\begin{tabular}{|l|l|l|}
\hline Region of Turkey & Project Numbers & $\begin{array}{l}\text { Total Housing } \\
\text { Units }\end{array}$ \\
\hline Marmara & 222 & 103546 \\
\hline Aegean & 105 & 31551 \\
\hline Mediterranean & 88 & 23736 \\
\hline Black Sea & 147 & 40695 \\
\hline Inner Anatolia & 288 & 96354 \\
\hline East Anatolia & 163 & 27656 \\
\hline $\begin{array}{l}\text { South-Eastern } \\
\text { Anatolia }\end{array}$ & 111 & 29928 \\
\hline TOTAL & 1124 & 353466 \\
\hline
\end{tabular}

Housing provision through MHA has both advantages and disadvantages. Most mass-housing projects have the planning principles of providing privacy at home, economical and fast construction of many housing blocks by the tunnel formwork system. One of the issues is that MHA thinks that it must generate high density settlements. Among the criticized aspects of MHA are:

- The head of MHA is the only authority concerned with selling urban land, making decisions on planning and determining the value of lands. Hence it is a kind of government supported monopoly in the housing sector (Geray, 2009).

- MHA has rights and authority of a financial institution among other finance offices and banks.

- MHA has extended power on city planning and tax exemption.

- The government makes it easier to sell public lands for the use of MHA.

In 2004, all duties and authority of the Urban Land Office were transferred to MHA. Based on this legal arrangement, 64.5 million square meters of land have been passed on to MHA's portfolio (Pulat Gökmen, Özsoy, 2008).

Some criticisms claim that MHA gives valuable urban lands with high unearned income in cities to the construction firms with low prices, and that there is no sufficient control on these land sales (Tuna, 2009). MHA declared that it has built homes for low-income groups. It gives 45-60 square meter flats to these families, but they are generally big families, and the flats do not fit these families (Tuna 2009). Some criticize that MHA is not very successful in 
organizing housing demands. In some cities, MHA could not sell 1515 housing units out of 1625 built flats (Tuna, 2009). Indeed MHA has built housing all over Turkey, but it does not consider economic conditions, housing needs, possible housing demands of settlement areas; MHA did not make feasibility work in chosen areas (Tuna, 2009).

It seems that the quantitative objectives of the Authority are mostly met: MHA has constructed 45,293 units. it is stated that by the end of 2007, MHA had aimed to start the construction of 50,000 residences and by mid-year, this goal had already been reached. But evidence suggests that mass housing projects have Known Primarily with aim of providing home ownership for low-income groups and it has covered overall economic and social goals. In other words, issues related to the quality of the projects has been overlooked In order to take advantage of low cost manufacturing techniques and minimal design projects (Kazaz and Birgonul,2005,1549).

During the last 6 years, the aims of creating a quality living environment, especially for the low-income, have not been implemented: instead, superficial numeric aims were adopted. The aims were set as:

- Improving the quality of the finished housing with new actors in the building production,

- Increasing the quality of near environment of housing and settlements,

- Supporting the level of justice among different user groups by bringing them together in the same living quarters,

- Homogenizing housing based on the common grounds of affordability,

- Obtaining the sustainability of mass-housing projects through participatory democratic methodology,

- Realizing the results of residential environments to become separable parts of the city due to the housing production system.

MHA uses a uniform format system that provides a variety of uniform Housing scheme in all cities and has not been analysis Qualitative and quantitative needs of users properly. Moderate groups in the city be lived in mass housing areas and urban centers have evacuated and this may give rise to concerns about changes in the environment with the historical record. One of the major criticisms of mass-housing projects in urban areas is related to construction in the suburbs for low-income people. Its great distance from the workplace and social networks May be causing discontent in the future and these areas may even be abandoned (Yuksel and Gokmen,2009,1-10). Also, because the goal of this project mass has been providing home ownership for low-income groups failed to fulfill its social and economic goals completely. 


\section{- Mass housing in Iran}

Due to various factors such as increasing young population and capital-centric approach to the housing issue, increasing housing demand in Iran lead to different methods in order to meet the major demand. The best solution is known as the mass housing that in fact, is industrializing building construction practices. In Iran due to the important role the housing sector and its interactions with Iran macroeconomic is allocated 20 to 30 percent of the budget to this issue. The construction industry's share in employment is more than $11 \%$ so there is a close connection between housing and other economic sectors. In order to create balance in Iran housing market would be built 1.5 million housing units annually and it seems that the best approach is industrial production or mass housing. In order to achieve mass project objectives, including time, cost and quality, managing of these projects is very important (Khanzadi et al,2010). Mass housing associations in Iran has been established from 2002 to support the private sector in housing (Fozeilinejad,2006,21).

Although modern methods of construction industry in the world have a lot of history and especially in the last twenty years has been a significant upward trend, the construction industry in Iran is in chaotic situation. The construction industry was introduced about 40 years and about 30 years ago reached to a significant point that due to the obvious dependence on international relations was interrupted after the revolution. Iran has experienced arrival of modern industry building since 50s including components made of plaster, steel, cement and concrete, steel mills and metal parts and ... which wanted to institutionalize the process of building and industrial methods in Iran. Ekbatan town, industrial city of Arak, housing complexes in Isfahan, Shiraz, Ahvaz, Karaj, dense villas in Gilan and Mazandaran, etc. have been among the successful efforts in the construction industry in Iran.

After the revolution, major housing development activities were founded on preparation and distribution of land so that each family build their own housing on the separate grounds. In fact single building replace with mass housing and in many cases, mass housing was done by unskilled persons. An obvious example of such a view can be seen in Nawwab huge complex (kamoori,2007,35). The result of such mass housing in Tehran showed that first, social indicators such territory, privacy and quality of housing has been compromised (sajadiyan,2001,424) and secondly, because mass housing program, downsizing and tower construction in Tehran applied in order to fix housing shortage and since been taken without considering the historical, political, economic, social and physical background has led to the destruction of Tehran social and natural environment (sajadiyan,2000,305). 
After implementation of first and second five-year plan of housing, mass housing gained an important place in the economic literature. Especially during the third plan meanwhile, legal basis, support of all institutions and executive agencies, mass housing guild was formed as mass-production management institution. With the formation of it and cooperative efforts between public and private sector in this regard, has been created a double success during the program so that we can say: mass housing subject institutionalized in housing policies and fewer plans can be followed and implemented regardless of mass subject (Jahani,2005,58). In the third plan was considered to PAK housing policy (savings, mass and downsizing). According to this law mass housing are projects that have 10 and more residential units in cities of more than 250000 people, 5 and more residential units in cities with populations of less than 250000 people and 3 and more residential units in villages. In other words, the concept of mass housing is a production scale concept that refers to buildings with a certain number of units (Jahani,2005,58). But in the fourth and fifth plans focused on Mehr housing that will be discussed below.

\section{Findings}

\section{Mehr Housing}

In view of the housing problems in Iran in housing master plan that its strategic and implementation documents drafted and finalized in 2006, anticipated 55 programs in 9 issues that one of its programs in low-income housing issue was transfer of land use right known as Mehr housing that in terms of paragraph "d" Note 6 of 2007 General Budget Law was prepared by Department of Housing and Urban Development and approved by the Council of Ministers. The target groups of this program were persons without housing, and low and middle income deciles (Office of Planning and Housing Economy,2010,16). According to the program, construction of about half a million housing units was on the agenda. In fact, Mehr housing is an example of a new mass housing era in Iran that designed with the aim of producing housing with low prices and remove land prices.

Implementation of Mehr housing plan began since 1386 that was structural cycle in policy and focused on the aim of providing suitable housing units for low-income groups. The plan goal was that by providing loan facilities at a rate of at least (4\%, 7\% and 9\%) and remove the cost of land from housing prices and pay half the cost of licensing and the cost of land preparation and infrastructure from housing sector subsidized, facilitate access to housing for low-income households (sumealoo,2010,6). In fact Mehr housing plan is considered in the form of assignment of transfer of land use right for the construction of small housing with average area of 75 square meters per unit and with the aim of reducing and eliminating costs 
of land from the cost of housing to adapt to low and middle-income households (Habibi et al, 2010, 8).

At the beginning, process of Mehr housing was in such a way that land for housing construction provided by the state to housing cooperatives. In this way, members of cooperatives should search for expert panel that were mass producers or whether they were required to build housing units. In practice, this process has not desired results and resulted in confusion and waste of time for the lack of expertise and technical management. For this purpose, a memorandum of understanding that was signed between the center of mass producer and the Ministry of Housing and Urban Development in March 2008, It was decided land initially adhered to the mass housing producers and after going through several steps in the implementation of foundation, members of cooperatives be introduced to mass producers because producers start to work first and cooperatives engage in affairs after studies and design and then they charge difference between building from their members. According to this, Housing Bank, pays first installment for construction and as guarantor of payment of the remaining facilities sign the agreement that this can produce desired results for speed up to administrative process.

Land transfer housing to eligible applicants is done according to the following criteria:

A) In cities with a population below 25 thousand up to 3 floors

B) In cities with a population of 25 to 100 thousand the number of classes between 2 to 4 floors.

C) In cities with a population of 100 thousand people up in the form of 3 to 4 floors (Ministry of Housing and Urban Development, 2009, 129).

\section{Consequence analysis of Mehr housing Plan}

The most important opportunity of Mehr housing policy was benefit from the earth in very low price (Saeedi Rezvani and Kazemi, 2011, 131). Other achievements of Mehr housing were: modified urban land use patterns (density of 250 persons per hectare compared with 126 and 78 persons per hectare in other cities), increasing of national production and economic growth (issuance of approximately 1.2 million housing permits during 3.5 years), increase the level of employment (according to the Mehr Housing Area, created 2.17 million jobs directly and indirectly), control the general level of prices and housing prices, increasing access to housing, improve household density in housing units, promoting economic justice, improve the quality of construction, mass production and industrialization expansion, foreign investment and management institutions increased (sumeloo,2010,7-8). Also downturn factors in the housing sector especially shopping residential units from mass producers listed 
as: high entire cost of the mass housing units, low concessional loans, presence of nonprofessionals in mass housing sector, lack of transfer of low cost land by government and lack of financial resources to purchase these units for low-income cities (Amini, 2008, 19). So what is certain cannot be overlooked from some positive outcomes of these projects, but because the current paper approach is more pathological approach, some problems and issues of this model will be analysis following in administrative process sector and economic, social, planning and environmental dimensions.

\section{(A) Problems of administrative process}

\section{- Lack of coordination between relevant organizations}

Like many other urban problems in Iran which is related to lack of integrated management, it has created multiple problems in planning and construction of these projects. Mehr housing is a joint plan between ministry of Housing and Urban Development, Ministry of Cooperatives and correspondent banks but the scope and role of each of the mentioned organizations has not been determined accuracy which causes rework and work in vain (Parhizgar \& Shahedi,2010,48). In fact, because of the substantial structural differences between the three institutions happens exchange ideas and procedures between them that cause severe administrative bureaucracy and increasing of construction time.

\section{- The administrative bureaucracy}

Among the problems of Mehr housing plan is the process of bureaucracy and get credit from facilitator banks that takes 6 to 12 months and its reason is lack of bank staff expertise in various stages confirmation of construction for financing deposit to manufacturers account (Parhizgar \& Shahedi, 2010, 47).

\section{- Licensing and provision of services by municipalities}

Since the location of these projects locate outside of service area \& outside of urban master and guided plans so municipalities are having difficulty in licensing and required urban facilities and services for the projects.

\section{- The lack of close monitoring on technical topics of Building}

Among the fundamental problems of the plan is lack of close monitoring of project supervisor and housing and urban development as the agency responsible for supervision. While in accordance with working group directive of Mehr housing, supervisor should be at the workshop and at each stage monitor on quality and implementation of the project but they have little presence in the workshop for monitoring which leads to carelessness and lack of supervision and reducing the strength of the building against earthquakes and other natural disasters (Parhizgar \& Shahedi, 2010, 48). 
Also consider the same conditions to prepare the ground And the same financial estimates To pay experts costs of Mehr housing has created serious problems for producers active in projects (Habibi et al, 2010, 11).

\section{- Lack of expertise of cooperatives in construction}

The majority of cooperative members in particular, the board of directors and director are unskilled in the field of construction and this reduce supervision by cooperatives as employers of the plan (Parhizgar \& Shahedi, 2010, 48).

\section{(B) Economic problems}

\section{- Cost of each unit for Applicants}

Given that Mehr housing applicants are mainly from the poor community and have not financial ability to provide housing units, the plan must be implemented in a way that has a minimum cost for project applicants. However, be asked from applicants to pay between 70 and 150 million Rials to take delivery of their housing units. But in the towns fewer than 25 thousand people due to the low price of land, one can at the expense of 80 to 100 million Rials purchase a 200-meter land and the amount of around 200 million riyals build singlefamily homes. This has led to no economic justification of Mehr housing plan in the city and many people want to be withdrawn (Parhizgar \& Shahedi, 2010, 48). Getting Land prices to zero that was one of the objectives of the development fourth program (and followed by Mehr housing target) has not been achieved because land preparation and provision of services in their areas away from cities in the overall computing, don't bring the land price to zero but the cost per square meter in the locations is far more than the price of land in a decent place in the cities (Etemad,2011,9) also huge profits that are considered by contractors for these projects are very high and sometimes reaches between 80 to 100 dollars per square meter and do not Monitor prices by any of concerned organizations (Parhizgar \& Shahedi,2010,48).

\section{- Repayment of loans}

Majority of applicants for the plan are among low income households in terms of earnings and first must pay an amount of about 70 to 150 million Rials for a home, The government also gives them bank facility equal to 200 million Rials; The bank facilities and refund loans will bring serious problems for applicants in the coming years (Parhizgar \& Shahedi, 2010, $48)$.

\section{- projects Cost of Mehr housing}

Due to Mehr housing was located in areas outside the cities will be charged for it the cost of land preparation (intact land and away from any facilities), the cost of providing services (due 
to the remoteness of city), the cost of access to the land (away from main roads and sometimes sub), high costs for providing services and ... that in practice cost of choice land for government will be much more than land of city.

\section{(C) Social problems}

\section{- Lack of success in recruiting target groups}

Failure to presentation a clear definition of target groups is known as one of the weaknesses of socio-economic development program and has vulnerable programs in this respect. Since the beginning of Mehr housing, it claims to provide housing for top third of low income households while in practice low decile withdrew from the program approximation because the two main conditions for register have been: ability to pay the bank installments and ability to pay the difference between operating costs with associated banking facilities. So the plan has not been able to attract a good target groups (Etemad, 2011, 9).

\section{- Social and class segregation}

Since most residents of these units, will be down or middle income class will follow a single caste and class segregation. Also it is anticipated that it will be cause of attraction for new immigrants that provides conditions for turning it into a ghetto poor.

\section{- Lack of attention to culture conditions}

Different types of housing should be identified and planned with study of city and the region cultural context, while it is rarely seen in Mehr housing. In particular, an area of 75 meters criteria, regardless of the circumstances variety of applicants and mass housing in form of buildings over 3 floors that in cities like Hashtgerd increased to 10 floors, are in this category (Habibi et al,2010,10). In addition, the cultural conditions of the small towns and also many people living in major cities usually is inconsistent with the pattern of apartment that caused not well received from Mehr housing projects.

\section{- Loss of identity}

Because most housing projects have located outside of city's physical locations are new and loss of identities spaces that without regard to socio-cultural issues are just places to live or shelter while making body is separated of the social construction (Gholami,2010,52). Some of their loss of identity can be seen in: becoming dormitory settlements, low levels of social cohesion, lack of a sense of belonging to living space and reducing public spaces and reducing socio-cultural interactions.

It should be noted that residential patterns have direct link to the socio-economic conditions and cultural needs of society So that policies implemented in the country to provide housing would not be necessarily applicable and successful in another area of the country. Thus, for 
considering the issue of housing you must identify the components of the identity of each location (Tavahon, 2004, 4) And this is something that has been forgotten in the Iran mass.

\section{- Create a platform for social ills}

Since Mehr housing project has done regardless of other urban facilities and services will provide growth areas a variety of social ills in long term. These locations are anticipated mainly in the suburban areas and so being away from the public spaces and general control over them, controlling crime and providing a secure environment in their community is more difficult than urban areas. Also, because these people have not a sense of identity and sense of belonging to a place and on the other hand, population density in these areas is greater, fields of abnormal behaviors are more prepared.

\section{(D) Urbanism problems}

\section{- Inappropriate Positioning}

Major housing sites are located in places that are outside of the metropolitan area so are not favorable for people and creates movement change of life pattern; this means that people are transferred from one place to another and this is while, delivery does not take place according to people's needs or supply is in places that demand don't exist (Gholami,2010,51). In other words, since in residential space there is a kind of social and cultural links, Moving on living people lead to disintegration of theses links and people are not reluctant to move, as well as the location because of the availability of land has done in not ready spaces and poor qualities (In terms of land drainage, sewerage provision, paving the way for follow-up and ...) which can lead to future problems (Etemad, 2011, 9).

In some cases, that has been constructed on agricultural land that This is in contradiction with the principles of national physical plans because agricultural land should not be under construction (Parhizgar \& Shahedi, 2010, 48). Also in the major metropolis of the country have been considered In the framework of the new towns, However, a major problem in the new towns Before construction of Mehr in Iran had been The lack of employment with residence that locations of housing in these spaces without employment spaces and other services for residents has doubled the problem.

\section{- Lack of attention to urban development plans}

Other topic discussed within the framework of Mehr housing is its relationship with urban development plans. Generally in locating suitable land for the construction of these housing units have been ignored urban development plans. The reason for this is the emphasis on affordable access to public lands that generally found in national resources lands and outside of city limits. On the other hand, these lands have not located in in the directions of urban 
expansion and are not in accordance with the purposes and principles of the urban development plans. This causes conflict between the location for the construction of Mehr housing projects and upstream plans (Abbasi, 2011, 102). Moreover, it should be noted that no link been established between the urban landscape and strategic criteria of urban development with these plans and not been identified its place in the development of cities.

\section{- Insufficient attention to the principles of urbanism}

In these projects, less attention has been to some principles of urbanism such as they are: lack of sufficient attention to the width of the streets in segmentation of Mehr housing estates and also lack of attention to skylight. For example, in some projects has been designed an 8-meter alley for 5-storey buildings that will cause crowding the streets. On the other direction of alleys should be north-south especially in cold areas but have mostly east-west direction and high buildings in the streets and causes the streets be far from the sun constantly, especially in winter. Also remove parking units to reduce cost is contrary to the principles of urbanism (Parhizgar \& Shahedi, 2010, 48). Lack of adequate lighting in units and reception of second light in the hall, lack of equipment to parking and storage for some units, small corridors and commissioning stairs and general joint constructions and traditional construction and noncompliance with article 19 of buildings are other defects. The problem of more than $90 \%$ of housing under construction is related to traditional building that causes weight gain and increase the duration of the construction. Also little attention paid to compliance with article 19 buildings. Of the total housing units under construction less than 5 percent have used industrial methods and less than $10 \%$ of units fully comply with principles and rules of article 19 (Parhizgar \& Shahedi, 2010, 48).

\section{- Lack of appropriate level of service}

Housing not only is physical location but contains all the necessary services and facilities for family welfare, employment programs, education and health (Shokrgozar, 2006, 31). To have ideal conditions for each residential unit it must have a series of basic amenities but in some units of these projects, this condition has not considered to reduce construction costs. Many urban areas of Mehr housing does not have the appropriate access and actual or potential infrastructure so that majority of towns that is running Mehr housing have no sewage system, water, electricity and other services that must be done before construction. Furthermoree have been forgotten public recreational spaces, open spaces, enough facilities related to housing, considering the cultural and educational facilities and correct distribution facilities and services in projects (Habibi et al, 2010, 10). 
Mehr Mass housing projects have been on the basis of purely residential space and since most of the projects located in the border town suffer from lack of social services and facilities. so, some projects have no infrastructure and service landuses (Green spaces, education, health, culture, sports and parking). Construction of thousands of housing units in a few months with no local considerations, including public and private access, and environmental amenities shows a lack of coordination and rational balance and physical planning.

The following table shows percent of public housing in various projects. As the table shows, while based on urban standards, 20 to $25 \%$ of the spaces devoted to public use, these figures are deficient in many projects. 
Table 4. Area and percent of public landuses except green space in Mehr housing projects

\begin{tabular}{|c|c|c|c|c|}
\hline \multirow[t]{2}{*}{ No. } & \multirow[t]{2}{*}{ Province Name } & \multirow[t]{2}{*}{$\begin{array}{l}\text { Total area } \\
\text { (ha) }\end{array}$} & \multicolumn{2}{|c|}{$\begin{array}{c}\text { public landuses area except } \\
\text { green space }\end{array}$} \\
\hline & & & ha & $\begin{array}{l}\text { Percent of } \\
\text { total }\end{array}$ \\
\hline 1 & Gilan & 229.4 & 28.9 & 12.6 \\
\hline 2 & East Azarbaijan & 1951.1 & 205.7 & 10.5 \\
\hline 3 & Khuzestan & 1535 & 129.9 & 8.5 \\
\hline 4 & Ardabil & 235.4 & 42.1 & 17.9 \\
\hline 5 & Central & 395 & 55 & 13.9 \\
\hline 6 & North Khorasan & 350 & 81.4 & 23.3 \\
\hline 7 & Bushehr & 71 & 14.5 & 20.5 \\
\hline 8 & Zanjan & 34.5 & 4.5 & 13.0 \\
\hline 9 & Kerman & 440 & 66 & 15.0 \\
\hline 10 & Hamedan & 67.1 & 20.9 & 31.1 \\
\hline 11 & Sistan and Baluchestan & 282 & 64.5 & 22.9 \\
\hline 12 & Qom & 215 & 34.6 & 16.1 \\
\hline 13 & Hormozgan & 610 & 128.7 & 21.1 \\
\hline 14 & Qazvin & 592.5 & 132.1 & 22.3 \\
\hline 15 & Lorestan & 259 & 61 & 23.6 \\
\hline 16 & Khorasan Razavi & 1644.1 & 126.1 & 7.7 \\
\hline 17 & Tehran & 1739 & 382 & 22.0 \\
\hline 18 & Kermanshah & 372.5 & 45.8 & 12.3 \\
\hline 19 & $\begin{array}{c}\text { Kohgiloyeh and } \\
\text { Boyerahmad }\end{array}$ & 72.79 & 5.67 & 7.8 \\
\hline 20 & Kurdistan & 197.6 & 44.5 & 22.5 \\
\hline 21 & Semnan & 213.2 & 31.8 & 14.9 \\
\hline 22 & Fars & 10.2 & 0.3 & 2.9 \\
\hline 23 & Total & 1151 & 17.6 & \\
\hline
\end{tabular}

Ayini, 2010, 41-42 
One of criticism of mass-housing projects is related to cases that be built on the edge of town and for low-income people. Their Far from work and social networks may lead to disappointment in the future and even caused to evacuate their homes (Kumkale,2009). Mehr Mass housing policy that implemented with these features despite reduce land use patterns and ultimately enhance the density Cause other problems for residents in the access to urban facilities. Because most of the residents are active in service jobs that generally are deployed in city and activities centers And is essential minimal facilities for their commute between work and life.

Also in terms of access, site or location of Mehr housing units in most cases is located away from the city that in addition to the unavailability of infrastructure, geographically located in a remote area and this causes reducing the willingness of applicants to settle in them (Parhizgar \& Shahedi, 2010, 48).

\section{- Increase the size of cities}

Assignment earth in the form of 99-year lease, doubling the production of housing policy (from 800 thousand units to 1.5 million units), the allocation of the bulk of credit to the housing sector, separate development outside of cities limits, residential development in the villages outside urban limits, are all indicative of a new movement with the outcome of uncontrolled urban expansion (Meshkini et al, 2011, 49). According to the survey locations for these projects in around cities, increase the limits of cities is of the major problems that is facing cities. Unfortunately, this is ignored despite the emphasis on limiting the growth of urban land and prevent of horizontal growth of cities and even in some cases, these projects has become instrument to enter certain zones to the cities limits (Abbasi, 2011,102).

\section{- Encourages dependence to personal transportation}

According to locate outside of the urban limits and since the Access for residents of these units are not considered and whereas residents of these areas Are dependent on the urban area In terms of employment and the provision of household purchases, need to traverse the distance between the residence and work And household necessities will lead to Dependence to personal transportation Which in today's urban development Has caused many problems And will lead to traffic and increased load on the network.

\section{(E) Environmental problems}

In addition to all the above problems, environmental justifications don't exist in these plans, and therefore will lead to increase the difficulties and problems in this area in the near future. Improper positioning in virgin lands and in some cases on agricultural land, shuffle local spaces and flora and fauna, failure to provide employment and services for residents and 
inadequate access will lead to the use of personal transport and tend to car. Provoke of sprawl and the subsequent increase their daily commutes and traffic in these areas are markers of adverse environmental consequences of the projects. Acts of mass politics in these projects that put on the agenda smooth housing construction and use the same building materials in different climatic zones in terms of architecture not only is outside of the scope of human comfort and much cost will be spent to its heat and cool, but also not coordinated with social and cultural characteristics of different regions, and in the long time lead to mental health problems, congestion and pollution crisis and the destruction of cities' breathing space which requires greater sensitivity to the issue.

\section{CONCLUSION}

Pay attention to the need for housing, especially low-income people needs; have followed different ways to resolve this major need. In this regard pay attention to modern manufacturing methods in housing including mass housing is inevitable. Given that the purpose of the mass housing is that optimize three major factors of time, cost and quality in housing, it has considered in housing programs of many countries. The first step in the realization of large-scale urban housing is removing barriers and management restrictions. Valid and active management not only helps to its planning and execution but also is necessary in various stages of studies, accounting, operation and maintenance. In this way, suitable platform is created for mass housing and is provided necessary conditions for its growth and development.

Iran's experience reviewed in this issue showed Mass housing is on the agenda with the goal of providing housing for low-income people and only in order to solve the problems of housing and the other aspect is neglected so finally will be lead to the destruction of the natural environment, social environment and city's physical environment. In Iran non suitable recognition of mass housing and lack of public awareness in this regard, weak rules and regulations and non-compliance with these weak rules by manufacturers and the weakness of culture of life in these buildings are ahead challenges in this regard (Arabi balaghi,2003,32). In fact, since every activity on the part of the land has long-term effects and effects on patches of its surroundings and even the whole city for a long period, as a result, the cost of inappropriate decisions about land is more than anything else. So It is essential that in addition to providing housing, be considered to other aspects of services and facilities and social life and try to be guided projects into the cities (eg Mehr housing) with complete preparations and to be used from the capacity within cities especially old urban tissue to not 
only enhanced productivity index of urban land but along with it can solve the problem of aging urban textures.

\section{REFERENCES}

-Abbasi, H., 2011, Escape of plan in Iran's housing policies: Mehr housing, urban researches Journal, No.35, pp. 98-103.

-Amin, B, 2008, Mass trend in recent years, Housing magazine, No.23.

-Ansari, MR, 2007, Housing and mass housing, Journal of technical and administrative managers Message, No.21, pp. 28-33.

-Arabi Balaghi, N., 2003, The requirements of the tall building as a form of Mass Housing, Mass Housing Journal, No. 9 and 10.

-Arjmandnia, A., 1991, Population and housing, Journal of Ecology, Volume 16, pp. 25-38.

-Ayeeni, M., 2010, Mehr housing: reform land use patterns and improving the quality of urban life, Journal of Housing Economics, No.47 and 48, pp. 31-43.

-Azizi, M., 2003, The density of the Urban Development: Principles and Criteria for determining urban density, Tehran University Press.

-Etemad, G., 2011, Mehr housing; solution or problem?, Journal of Bon, No.86, pp. 6-9.

-Fozeilinejad, M., 2006, Mass housing and its role in economic development, Rehabilitation Journal, No.18, Winter, pp. 20-22.

Geray, C., 2009, Toplumsal Konut Siyasası Açısından TOK Uygulamaları, TOK Çalışmaları Üzerine Değerlendirmeler (Implimentations of MHA in terms of Social Housing Policy), Series of Chambers of Architecture, pp. 77-87, stanbul.

-Gholami, M.J, 2010, Pathology of Mehr housing Plan, Abadi Journal, No.69, pp. 50-55.

-Habibi, K. et al., 2010, Cash and pathology of Mehr housing policy and operational planning in Iran, Abadi Journal, Issue 69, pp. 6-13.

-Heydari Chaîne, R, and Rezatabe Azgami,, S.Kh, 2010, Role of City Development Strategy (CDS) in the policy of providing urban low-income housing groups, case study: the city of Rasht, Journal of Human Geography Research, No.73, pp: 59-82.

-Jahani, M., 2005, Several considerations on the concept of mass housing, Journal of mass housing, No. 15 , pp: 58-59.

-Kamoori, P., 2007, Mass housing: Why? And how?, journal of technical and administrative managers Message, No. 21, pp. 34-37. 
-Meshkini, A. et al., 2011, The impact of land-grant policies and public housing in the physical development in Iran (Case Study of Kermanshah), Geography and Development, No. 23, pp. 47-67.

-Ministry of Housing and Urban Development (National Land and Housing organization), 2006, The Housing Master Plan, the Department of Housing and Urban Development of the Islamic Republic of Iran, Tehran.

-Ministry of Housing and Urban Development (National Land and Housing organization), 2009, an excerpt of specific regulations of the Ministry of Housing and Urban Development, Department of Housing and Urban Development of the Islamic Republic of Iran, Tehran.

-Moghani Rahimi, B, and Bayramipoor, A., 2008, Take a look at negative consequences of mass housing and Downsizing of residential units, Journal of Development of geography education, No.2, pp. 53-56.

-Naghizadeh, M., 2004, Mass housing, downsizing and its implications, Journal of housing and Revolution, No. 105.

-Nasiri, I, 2009, Mass housing: economic efficiency and its impact on the optimum use of land in urban areas, Andishe Gostar Saipa Journal, No. 88.

-Office of Housing Planning and Economics, 2010, Mehr Housing: a New Approach in the housing sector, Journal of Housing Economics, No. 47 and 48, pp. 12-20.

-Parhizgar, A and Shahedi, N., 2010, An overview of Mehr housing Plan in the towns of under 25,000 people, Abadi Journal, No.69, Pp. 44-49.

-Pulat, Gökmen G., Özsoy, A., 2008, Emerging Trends and Problems of Housing Supply in Urban Housing Transformations in Istanbul, IAG $50,30^{\text {th }} . J u n e-3^{\text {rd }}$ July 2008 , University of Tasmania, Book of Abstracts, p. 139, Hobart, Australia.

-Saeedi Rezvani, N, and Kazemi. D., 2011, Recognizing the framework of endogenous development in proportion to review current housing development policies (Mehr housing), case study: city of Natanz, human geography studies Journal, No.75, pp. 113-132.

-Sajadian, N., 2000, Analyzing the impact of Mass and Tower construction policy on Natural and social figures of Tehran, Tehran University Faculty of Literature and Human Sciences Journal, pp. 305-321.

-Sajadian, N., 2001, Geographical analysis of urban housing policies of Tehran and its, Tehran University Faculty of Literature and Human Sciences Journal, pp. 407-430.

-Shokrgozar, A., 2006, Urban housing in Iran, Haghshenas press, Tehran.

-Sumealoo, A., 2010, Mehr housing: Structural rotation in housing policy and its achievements, Journal of Housing Economics, No.47 and 48, pp. 6-8. 
-Tavahon, A., 2004, Housing planning, Shahrdariha Journal, No. 62.

-Tuna, B., 2009, TOK Kime ve Nasıl Konut Yapıyor?, TOK Çalışmaları Üzerine Değerlendirmeler (To whom and how MHA build houses; Some Assessments on Works of MHA), Chamber of Architects of Turkey, pp. 71-76, Ankara.

How to cite this article:

Abbaszadeh G. Pathology of mass housing projects in iran (mehr housing plan). J. Fundam. Appl. Sci., 2016, 8(3S), 885-915. 